\title{
Comparison of allozyme variability in a native and an introduced species of Lonicera
}

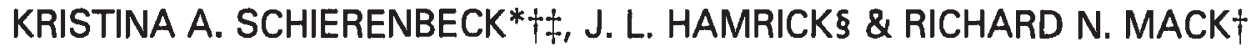 \\ †Department of Botany, Washington State University, Pullman, WA 99163, $\ddagger$ Savannah River Ecology Laboratory, Aiken, \\ SC 29802, and §Departments of Botany and Genetics, University of Georgia, Athens, GA 30602, U.S.A.
}

Levels of allozyme variation are compared between a diploid invasive plant species, Lonicera japonica Thunb. $(2 n=18)$ and its polyploid native congener, Lonicera sempervirens L. $(2 n=36)$. Both are woody perennials and were sampled within the native range of $L$. sempervirens in the south-eastern United States where L. japonica has been an invader since the late 19th century. Genetic structure and allozyme diversity were determined for nine and ten populations of $L$. sempervirens and $L$. japonica, respectively. Genetic variation within $L$. japonica is similar to that in other species with similar life history traits (per cent polymorphic loci, $P_{\mathrm{s}}=75$ per cent, mean alleles per polymorphic locus, $A_{\mathrm{ps}}=2.28$, and total genetic diversity, $H_{\mathrm{t}}=0.216$ ); $L$. sempervirens has even higher genetic variation than $L$. japonica $\left(P_{\mathrm{s}}=91\right.$ per cent, $A_{\mathrm{ps}}=2.60$ and $\left.H_{\mathrm{t}}=0.283\right)$. Although both species have high levels of genetic diversity, this may be less important than their life history traits to their success in early successful habitats. However, establishment of a relationship between success in naturalization for woody perennials and levels of genetic diversity is hampered by the paucity of comparable records for other native: alien congeneric pairs.

Keywords: genetic variation, introduced populations, Lonicera japonica, Lonicera sempervirens, native populations.

\section{Introduction}

Studies of invasive plant species (sensu Mack, 1985) have often involved a search for generalizations about these species' life history and genetic characteristics (Baker, 1974, 1986). However, several comprehensive syntheses (see Barrett \& Richardson, 1986; Gray, 1986; Barrett \& Shore, 1989; Warwick, 1990) have revealed few discernible patterns. Their detection may be hampered, however, by comparisons among invasive species with different modes of reproduction and habits or that occur in different successional stages or in new ranges. This current dilemma is illustrated by the lack of consensus regarding the relation of genetic variability to the invasive ability of plants, i.e. some invasive species maintain low levels of genetic variation whereas others are highly variable (Barrett \& Richardson, 1986). Alternatively, grouping species by life history traits and geographical range has been successful in detecting associations between genetic diversity and life history characteristics for plant

*Correspondence: Department of Biology, California State University, Fresno, CA 93740, U.S.A. species in general (Hamrick et al., 1979; Loveless \& Hamrick, 1984; Hamrick et al., 1992).

Thus, first categorizing invasive species by life history traits and then looking for patterns through the comparison of taxonomically related noninvasive species may provide new insight. For example, invasive species with low levels of allozyme diversity often share life history traits, e.g. inbreeding and polyploidy (Warwick, 1990) or the annual habit with selfing breeding systems (Barrett \& Richardson, 1986).

We examined the genetic structure and diversity of two perennial Lonicera (Caprifoliaceae) congeners, one an aggressive invader and the other a common but noninvasive native. These honeysuckles are the diploid $(2 n=18)$ Lonicera japonica Thunb., native to temperate eastern Asia, and the tetraploid $(2 n=36) L$. sempervirens $\mathrm{L}$., native to the eastern United States. Lonicera japonica was introduced as an ornamental in the early to mid-19th century (exact date undocumented); its rapid spread was noted in southwest Virginia in 1892, Florida in 1897 and Athens, Georgia in 1900 (Leatherman, 1955). Lonicera sempervirens is far more widespread than its native congeners in North America and may be considered a colonizer (Radford 
et al., 1968). Parentage of the allopolyploid $L$. sempervirens is not known, but based on morphology its extant native diploid congeners, $L$. flava and $L$. dioca, are good candidates as putative parents $(K$. A. Schierenbeck, personal observation) and as possible sources of variation.

Lonicera japonica and $L$. sempervirens now occur sympatrically in the southeastern United States; both outcross and also persist clonally to an unknown extent. Although these bird-dispersed species (Snow \& Snow, 1988) are common in mid-successional sites, the blanket-like clonal growth of $L$. japonica contributes to its local influence in the reduction of species diversity and alteration of successional patterns (Oosting, 1942; Slezak, 1976; Sasek, 1983). Both $L$. japonica and $L$. sempervirens have similar photosynthetic rates (Schierenbeck, 1992) but different patterns of biomass allocation, both spatially and temporally (Sasek \& Strain, 1991; Schierenbeck, 1992).

Natural hybrids between subgenera in Lonicera are unknown, and no seeds have been obtained following artificial pollination (Sax \& Kribs, 1930). We also found no evidence for hybridization between $L$. japonica (subgenus Chamaecerasus) and L. sempervirens (subgenus Pericylmenum).

Comparing a native species growing sympatrically with an invasive congener has been suggested as a means of detecting the attributes that characterize invasive species (Baker, 1965). Lonicera japonica and $L$. sempervirens provide a good basis for such a comparison, given their similarities in taxonomy, habitat, successional role, growth form, dispersal mechanism and physiology (Schierenbeck, 1992). Consequently, we employed starch gel electrophoresis to examine genetic diversity within and among populations of these two species. We then compared our data with those for other woody perennial angiosperms and invasive species with similar life history traits.

\section{Materials and methods}

Collection sites for this study were chosen in westcentral South Carolina and eastern Georgia (Fig. 1). Vegetative cuttings were collected from 10 and nine populations of $L$. japonica and $L$. sempervirens, respectively, in April and May 1991. The number of individuals from each population ranged from six to 14 in L. sempervirens and seven to 20 in L. japonica. 'Population' as used in this study is defined as a group of individuals separated from other groups of individuals by at least $20 \mathrm{~km}$. This distance is thought to be sufficient to ensure extremely low levels of gene flow between populations through pollination (Handel, 1983; Johnsgard, 1983; Waddington, 1983). We collected cuttings from individuals at least $50 \mathrm{~m}$ apart to avoid sampling the same clone twice. The sporadic occurrence of individual clones made collecting larger numbers of individuals per population impractical. Cuttings from each individual were rooted with Rootone $^{\mathrm{TM}}$ and cultivated in a greenhouse until sampled for electrophoresis.

Samples were prepared for electrophoresis by first grinding a small amount of mature leaf tissue in liquid nitrogen and extracting the enzymes in phosphate buffer (Soltis et al., 1983). Electrophoresis was performed for all systems using 11 per cent Sigma ${ }^{\mathrm{TM}}$ starch. Both species were scored and analysed for 13 enzyme systems (see Table 1 for buffers): aspartate aminotransferase (AAT, EC 2.6.1.1), diaphorase (DIA, EC 1.6.99.-), fluorescent esterase (FE, EC 3.1.1.1), fructose-1,6-diphosphatase (F16, EC 3.1.3.11), isocitrate dehydrogenase (IDH, EC 1.1.1.42), leucine aminopeptidase (LAP, 3.4.11.1), malate dehydrogenase (MDH, EC 1.1.1.37), malic enzyme (ME, EC 1.1.1.40), 6-phosphogluconate dehydrogenase (6PGD, EC 1.1.1.44), phosphoglucoisomerase (PGI, EC 5.3.1.9), phosphoglucomutase (PGM, EC 5.4.2.2), shikimate dehydrogenase (SKDH, EC 1.1.1.25) and triose-phosphate isomerase (TPI, EC 5.3.1.1). These enzymes provided 24 and 22 scorable loci for $L$. japonica and $L$. sempervirens, respectively. In both species the number of independent banding zones as well as the banding patterns within each variable zone were largely consistent with expected enzyme substructure and compartmentalization. Thus, with one exception (see below) the banding patterns seen were consistent with diploid inheritance and were treated as such in our analyses. Because sample sizes were small, we concentrated on obtaining the maximum number of scorable loci to gain accurate estimates of genetic variability (Nei, 1978).

Genetic diversity within each species was summarized using percentage polymorphic loci $\left(P_{s}\right.$ (subscript $s$ indicates species)), mean number of alleles per locus $\left(A_{\mathrm{s}}\right)$ and per polymorphic locus $\left(A_{\mathrm{ps}}\right)$ and mean gene diversity $\left(H_{\mathrm{es}}\right)$ per locus, as described by Hamrick \& Godt (1989). Equivalent statistics were calculated at the population level $\left(P_{\mathrm{p}}, A_{\mathrm{p}}, A_{\mathrm{pp}}\right.$ and $H_{\mathrm{ep}}$ (subscript $\mathrm{p}$ indicates population)) following Hedrick (1985). The mean effective number of alleles per locus was calculated within populations $\left(A_{\text {ep }}\right)$ and species $\left(A_{\text {es }}\right)$ $\left[A=1 /\left(\Sigma p_{i}^{2}\right)\right] . H_{\mathrm{T}}$ is defined as total mean genetic diversity (Nei, 1973). Within each population, each polymorphic locus was examined using Wright's fixation index $\left(F_{\text {IS }}\right)$ for deviations from expected Hardy-Weinberg genotype frequencies (Wright, 1922; Li \& Horvitz, 1953). Genetic differentiation among populations was measured using a $\chi^{2}$ analysis to test 


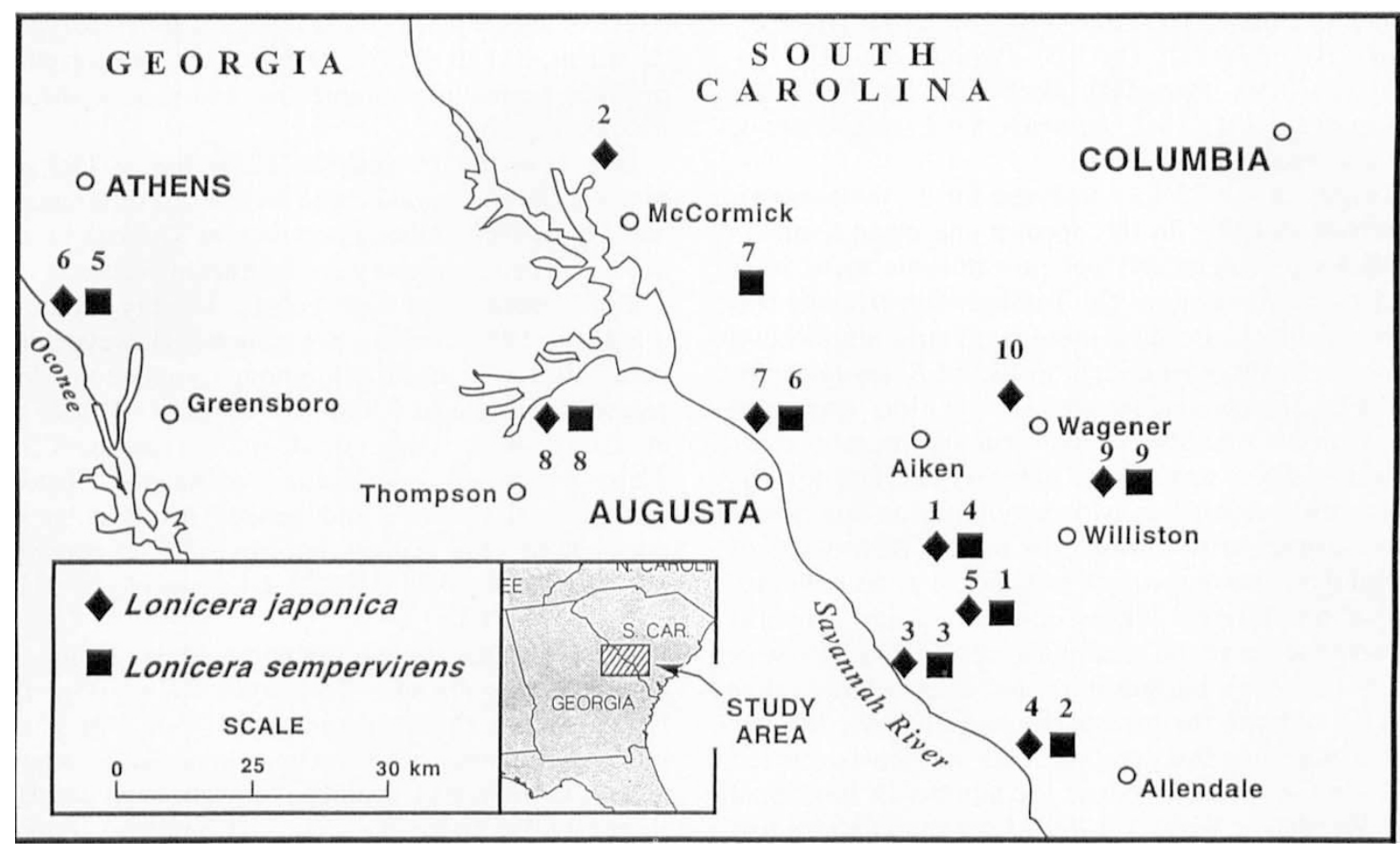

Fig. 1 Locations of nine populations of Lonicera sempervirens and 10 populations of L. japonica in the southeastern United States from which samples were collected for electrophoretic analysis.

Table 1 Electrode and gel buffers used to resolve 13 enzyme systems in Lonicera japonica and L. sempervirens

\begin{tabular}{|c|c|c|c|}
\hline Electrode buffer & Gel buffer & Enzymes & References \\
\hline $\begin{array}{l}0.3 \mathrm{M} \text { boric acid } \\
0.1 \mathrm{M} \mathrm{NaOH} \\
\text { pH } 8.6\end{array}$ & $\begin{array}{l}0.015 \mathrm{~m} \text { Tris } \\
0.004 \mathrm{M} \text { citric acid } \\
\text { pH } 8.6\end{array}$ & $\begin{array}{l}\text { LAP, PGM, } \\
\text { AAT }\end{array}$ & Mitton et al. (1977) \\
\hline $\begin{array}{l}0.388 \mathrm{M} \mathrm{LiOH} \\
0.263 \mathrm{~m} \text { boric acid } \\
\text { pH } 8.0\end{array}$ & $\begin{array}{l}0.006 \mathrm{M} \text { citric acid } \\
0.004 \mathrm{M} \mathrm{LiOH} \\
0.029 \mathrm{M} \text { boric acid } \\
0.033 \mathrm{M} \text { Tris } \\
\text { pH } 7.6\end{array}$ & $\begin{array}{l}\text { PGI, TPI, } \\
\text { FE }\end{array}$ & $\begin{array}{l}\text { Modified from } \\
\text { Adams \& Joly (1980) }\end{array}$ \\
\hline $\begin{array}{l}0.22 \mathrm{M} \text { Tris } \\
0.085 \text { citric acid } \\
\text { pH } 7.5\end{array}$ & $\begin{array}{l}0.008 \mathrm{M} \text { Tris } \\
0.003 \mathrm{M} \text { citric acid } \\
\text { pH } 7.5\end{array}$ & $\begin{array}{l}\text { ME, DIA, } \\
6 \mathrm{PGD}\end{array}$ & $\begin{array}{l}\text { Modified from } \\
\text { Shaw \& Prasad (1970) }\end{array}$ \\
\hline $\begin{array}{l}0.4 \mathrm{M} \text { citric acid } \\
\text { (trisodium salt) } \\
\mathrm{pH} 7.0\end{array}$ & $\begin{array}{l}0.009 \mathrm{M} \mathrm{L} \text {-histidine } \\
\mathrm{HCl} \text {, monohydrate } \\
\text { pH } 7.0\end{array}$ & $\begin{array}{l}\text { IDH, MDH, } \\
\text { SKDH, F16 }\end{array}$ & $\begin{array}{l}\text { Modified from } \\
\text { Gottlieb (1981) }\end{array}$ \\
\hline
\end{tabular}

Full names of enzymes are given in Material and methods.

for heterogeneity in allele frequencies among populations (Workman \& Niswander, 1970) and Nei's gene diversity statistics to assess the partitioning of total genetic diversity within and among populations (Nei, 1973, 1977).

\section{Results}

The resolution of 13 enzyme systems provided data for the following loci: Aat-1(B), Aat-2(B), Dia-1(B), F161(B), Fe-1(J), Fe-2(B), Fe-3(S), Idh-1(J), Lap-1(B),

(c) The Genetical Society of Great Britain, Heredity, 75, 1-9. 
$M d h-1(\mathrm{~J}), M d h-2(\mathrm{~B}), M d h-3(\mathrm{~B}), M e-1(\mathrm{~B}), M e-2(\mathrm{~B})$, 6Pgd-1(B), 6Pgd-2(B), Pgi-1(B), Pgi-2(J), Pgi-3(B), Pgi4(S), Pgm-1(B), Pgm-2(B), Skdh-1(B), Tpi-1(B), Tpi$2(\mathrm{~B})$ and $T p i-3(\mathrm{~B})(\mathrm{J}=L$. japonica, $\mathrm{S}=$ L. sempervirens, $\mathrm{B}=$ both species)

Twenty of the 22 loci analysed for $L$. sempervirens were polymorphic. In this species, the mean numbers of alleles per locus and per polymorphic locus were 2.45 and 2.60 , respectively. Total genetic diversity was 0.283 (Table 2). Because there is no strict duplication of loci in an allopolyploid, most loci of $L$. sempervirens could be interpreted as diploid loci (loci expressed through only one homologous pair of chromosomes). However, Pgi-3 was a fixed heterozygote and for this analysis was treated as two monomorphic loci. Fixed heterozygotes arise through the pairing of two sets of homologous chromosomes in which a gene is homozygous for different alleles in each set and a hybrid genotype arises in the resulting allopolyploid (Roose \& Gottlieb, 1976). Furthermore, for many of the other enzyme systems, the two species had the same number of loci indicating that gene silencing may have occurred in $L$. sempervirens to reduce the number of functional loci (Weeden \& Wendel, 1989). Lonicera japonica had 75 per cent of its loci polymorphic, 2.28 alleles per polymorphic locus, 1.96 alleles per locus and total genetic diversity was 0.216 (Table 2 ).

Further differences in genetic diversity were also apparent within populations of these two species. Within L. sempervirens populations, on average there were 67.7 (range 50-82) per cent polymorphic loci, $2.31(2.18-2.44)$ alleles per polymorphic locus, 1.51 (1.41-1.66) effective alleles per locus and an expected heterozygosity of $0.250(0.205-0.303)$. Lonicera japonica populations had on average 53.8 (range 33.3, 50-62.4) per cent polymorphic loci, $2.20(2.07-2.33)$ alleles per polymorphic locus, 1.34 (1.21-1.44) effective alleles per locus, and expected heterozygosity of $0.189(0.120-0.226)$. There was no correlation between population sample size and genetic diversity for either species.

Based on the $\chi^{2}$ analysis, 12 of the 18 loci polymorphic for $L$. japonica had significant differences in allele frequencies among populations whereas 11 of 22 loci for $L$. sempervirens were significant (Table 3 ).

Both species had high genetic identity indices $(I)$ (Hedrick, 1985) among populations. However, more variation for $I$ occurred among populations in $L$. sempervirens (range 0.826-0.972, mean $=0.904$ ) than in L. japonica (range 0.902-0.987, mean $=0.960$ ). There was no significant correlation between geographical distance and genetic distance between populations for either species ( $L$. sempervirens, $r=0.296$, d.f. $=35, P<0.2 ; L$. japonica, $r=0.212$, d.f. $=44, P<0.2$ )

On a population-by-population basis, $L$. japonica displayed significant deviations $(P<0.05)$ from Hardy-Weinberg expectations in 27 of $240 \chi^{2}$-tests (twice the number expected by chance alone), whereas L. sempervirens had significant deviations in 24 of 189 $\chi^{2}$-tests (also twice the expected number). Lonicera sempervirens had negative fixation indices, indicating an excess of heterozygotes and significant deviations from Hardy-Weinberg expectations for Aat-1 (four populations) and $L a p-1$ (one population). The remaining deviations, although significant, indicated a lack of heterozygotes, a result predictable for the number of $\chi^{2}$-tests. The mean $F_{\text {Is }}$ value for $L$. sempervirens was 0.081 and was not significant $\left(\chi_{1}^{2}=0.55 ; P<0.50\right)$. In general, $L$. japonica conformed to Hardy-Weinberg expectations; all the significant deviations were for an excess of homozygous individuals, but the overall frequency of deviations was low. $F_{\text {Is }}$ values varied widely across loci for both species, but were generally

Table 2 Percentage polymorphic loci, mean number of alleles per locus and per polymorphic locus, and total genetic diversity within Lonicera japonica and $L$. sempervirens compared with the mean for 196 species with similar life history characters

\begin{tabular}{lccc}
\hline $\begin{array}{l}\text { Percentage } \\
\text { polymorphic loci } \\
\left(P_{\mathrm{s}}\right)\end{array}$ & $\begin{array}{c}\text { Mean number of } \\
\text { alleles/locus } \\
\left(A_{\mathrm{s}}\right)\end{array}$ & $\begin{array}{c}\text { Alleles per } \\
\text { polymorphic locus } \\
\left(A_{\mathrm{ps}}\right)\end{array}$ & $\begin{array}{c}\text { Total genetic } \\
\text { diversity } \\
\left(H_{\mathrm{t}}\right)\end{array}$ \\
\hline $\begin{array}{l}\text { Lonicera sempervirens } \\
\quad 90.91\end{array}$ & 2.45 & 2.60 & 0.283 \\
$\begin{array}{l}\text { Lonicera japonica } \\
\quad 75.00\end{array}$ & 1.96 & 2.28 & 0.216 \\
$\begin{array}{l}\text { Other woody perennial angiosperms } \\
\quad 65.00\end{array}$ & 2.22 & 2.88 & 0.177 \\
\hline
\end{tabular}

$†$ From Hamrick et al. (1992). 
Table 3 Gene diversity statistics for 20 and 18 polymorphic loci in Lonicera sempervirens and L. japonica, respectively

\begin{tabular}{|c|c|c|c|c|c|c|c|}
\hline Locus & No. of alleles & $H_{\mathrm{T}}$ & $H_{\mathrm{S}}$ & $D_{\mathrm{ST}}$ & $G_{\mathrm{ST}}$ & \multicolumn{2}{|c|}{$\chi^{2}$ (d.f.) } \\
\hline \multicolumn{8}{|c|}{ Lonicera sempervirens } \\
\hline Aat-1 & 2 & 0.4625 & 0.4084 & 0.0541 & 0.1169 & $19.64^{*}$ & $(8)$ \\
\hline Aat-2 & 2 & 0.2098 & 0.1914 & 0.0184 & 0.0875 & 14.71 & (8) \\
\hline Lap-1 & 2 & 0.4762 & 0.3701 & 0.1061 & 0.2228 & $34.76^{* *}$ & (8) \\
\hline$P g m-1$ & 2 & 0.4711 & 0.3645 & 0.1066 & 0.2263 & $35.76^{* *}$ & (8) \\
\hline$P g m-2$ & 2 & 0.0973 & 0.0915 & 0.0058 & 0.0591 & 9.23 & (8) \\
\hline $\mathrm{Fe}-2$ & 3 & 0.6005 & 0.4813 & 0.1192 & 0.1985 & $72.07^{* *}$ & (8) \\
\hline$F e-3$ & 4 & 0.6835 & 0.5664 & 0.1171 & 0.1713 & $179.94^{* *}$ & (24) \\
\hline Pgi-1 & 2 & 0.2616 & 0.2442 & 0.0174 & 0.0665 & 11.17 & $(8)$ \\
\hline$T p i-1$ & 3 & 0.0582 & 0.0541 & 0.0041 & 0.0700 & 24.57 & (16) \\
\hline$T p i-2$ & 2 & 0.3170 & 0.2657 & 0.0513 & 0.1618 & $26.21^{* *}$ & $(8)$ \\
\hline$T p i-3$ & 3 & 0.1039 & 0.0955 & 0.0084 & 0.0809 & 22.44 & (16) \\
\hline F16-1 & 5 & 0.7690 & 0.7046 & 0.0643 & 0.0837 & $51.10^{*}$ & (32) \\
\hline$M d h-2$ & 2 & 0.0713 & 0.0646 & 0.0068 & 0.0951 & 15.40 & (8) \\
\hline$M d h-3$ & 3 & 0.0912 & 0.0771 & 0.0141 & 0.1550 & $33.11^{* *}$ & (16) \\
\hline$S k d h-1$ & 3 & 0.5446 & 0.4023 & 0.1423 & 0.2613 & $124.62^{* *}$ & (16) \\
\hline $6 P g d-1$ & 2 & 0.1327 & 0.1262 & 0.0064 & 0.0486 & 8.17 & $(8)$ \\
\hline 6Pgd-2 & 2 & 0.2449 & 0.2244 & 0.0205 & 0.0837 & 14.05 & (8) \\
\hline Dia-1 & 2 & 0.4974 & 0.3332 & 0.1643 & 0.3302 & $55.47^{* *}$ & (8) \\
\hline$M e-1$ & 2 & 0.1544 & 0.1445 & 0.0099 & 0.0644 & 10.69 & (8) \\
\hline$M e-2$ & 4 & 0.5878 & 0.4962 & 0.0916 & 0.1558 & $43.95^{* *}$ & (24) \\
\hline Mean & & 0.3107 & 0.2594 & 0.0513 & 0.1651 & & \\
\hline \multicolumn{8}{|c|}{ Lonicera japonica } \\
\hline Aat-1 & 2 & 0.1036 & 0.0888 & 0.0148 & 0.1431 & $41.79^{* *}$ & (9) \\
\hline Aat-2 & 2 & 0.1457 & 0.1402 & 0.0055 & 0.0379 & 11.98 & (9) \\
\hline$P g m-1$ & 2 & 0.2228 & 0.2050 & 0.0178 & 0.0801 & $21.94^{* *}$ & (9) \\
\hline$P g m-2$ & 2 & 0.0778 & 0.0672 & 0.0106 & 0.1365 & $40.40^{* *}$ & (9) \\
\hline $\mathrm{Fe}-1$ & 3 & 0.5357 & 0.4493 & 0.0864 & 0.1614 & $64.51^{* *}$ & (18) \\
\hline Pgi-2 & 2 & 0.4907 & 0.4841 & 0.0066 & 0.0134 & 4.12 & (9) \\
\hline$P g i-3$ & 3 & 0.5369 & 0.4929 & 0.0439 & 0.0818 & 51.81 ** & (18) \\
\hline Tpi-2 & 2 & 0.5000 & 0.4540 & 0.0460 & 0.0921 & $28.72^{* *}$ & (9) \\
\hline$T p i-3$ & 3 & 0.0129 & 0.0124 & 0.0005 & 0.0370 & 15.21 & (18) \\
\hline F16-1 & 2 & 0.3940 & 0.3681 & 0.0259 & 0.0658 & $18.29 *$ & (9) \\
\hline$I d h-1$ & 2 & 0.1927 & 0.1808 & 0.0119 & 0.0617 & 15.41 & (9) \\
\hline$M d h-2$ & 2 & 0.4966 & 0.4131 & 0.0835 & 0.1682 & $45.98^{* *}$ & (9) \\
\hline$M d h-3$ & 3 & 0.0283 & 0.0263 & 0.0019 & 0.0690 & 25.84 & (9) \\
\hline$S k d h-1$ & 2 & 0.3876 & 0.3483 & 0.0393 & 0.1014 & $27.39^{* *}$ & (9) \\
\hline $6 P g d-1$ & 2 & 0.1295 & 0.1209 & 0.0087 & 0.0670 & $21.17^{*}$ & (9) \\
\hline $6 P g d-2$ & 2 & 0.0126 & 0.0120 & 0.0006 & 0.0495 & 15.65 & (9) \\
\hline Dia-1 & 2 & 0.4960 & 0.4233 & 0.0727 & 0.1467 & $46.05^{* *}$ & (9) \\
\hline$M e-2$ & 3 & 0.4160 & 0.3599 & 0.0561 & 0.1350 & $64.23^{* *}$ & (18) \\
\hline Mean & & 0.2878 & 0.2581 & 0.0296 & 0.0915 & & \\
\hline
\end{tabular}

Key to abbreviations for genetic diversity statistics: $H_{\mathrm{T}}$, total genetic diversity; $H_{\mathrm{s}}$, mean genetic diversity within populations; $D_{\mathrm{ST}}$, gene diversity among populations; $G_{\mathrm{ST}}$, proportion of total variation resulting from differences among populations. Enzyme abbreviations are found in Materials and methods.

$\chi^{2}$ values test the hypothesis that there are no significant differences among populations.

${ }^{*} P \leqslant 0.05,{ }^{* *} P \leqslant 0.01$.

more positive for $L$. japonica, indicating slightly more heterozygote deficiencies $\left(\right.$ mean $F_{\text {IS }}=0.118, \chi_{1}^{2}=2.20$; $P<0.10)$.

Among-population variation was higher for $L$. sempervirens $\left(G_{\mathrm{ST}}=0.165\right)$ than for $L$. japonica
$\left(G_{\mathrm{ST}}=0.092\right)$ (see Table 3$)$. On a per locus basis, $G_{\mathrm{ST}}$ values for $L$. japonica ranged from 0.0134 to 0.1682 . Thus, most of the variation (90 per cent) for $L$. japonica occurs within populations. For L. japonica, $D_{\mathrm{ST}}$ and $G_{\mathrm{ST}}$ showed similar patterns for most loci. 
Lonicera sempervirens had $G_{\mathrm{ST}}$ values ranging from 0.0486 to 0.3302 and most of the total variation ( 83 per cent) occurs within populations. The higher $G_{\mathrm{ST}}$ for $L$. sempervirens could be caused to some degree by the higher proportion of populations with sample sizes below 10 individuals. When those $L$. sempervirens populations with sample sizes $>10$ were analysed the $G_{\mathrm{ST}}$ was 0.102 , confirming that sample size per se did have some effect on the value of $G_{\mathrm{ST}}$.

\section{Discussion}

Among the populations sampled in South Carolina and Georgia, L. sempervirens has higher genetic variability than $L$. japonica as measured by per cent polymorphic loci, mean number of alleles/locus and total genetic diversity. Values of per cent polymorphic loci $\left(P_{s}\right)$ for both species are consistently higher than those for previously reported species of similar taxonomic status (dicots, $P_{\mathrm{s}}=44.8$ ), geographical range (widespread, $P_{\mathrm{s}}=58.9$ ), mating system (outcrossing, via animals, $P_{s}=50$ ), mode of reproduction (sexual, $P_{\mathrm{s}}=51.6$; sexual and asexual, $P_{\mathrm{s}}=43.8$ ), and habitat (mid-successional, $P_{\mathrm{s}}=47.6$ ) (Hamrick \& Godt, 1989; Hamrick et al., 1992).

Long-lived perennial species have a mean withinpopulation variation of 49.3 per cent polymorphic loci, 1.76 alleles per locus and a mean total genetic diversity of 0.148 (Hamrick et al., 1992); all values are lower than for either $L$. japonica or L. sempervirens.

The proportions of total diversity among populations $\left(G_{\mathrm{ST}}\right)$ for $L$. japonica $(0.092)$ and $L$. sempervirens $(0.165)$ are comparable to the $G_{\mathrm{ST}}$ values found in other long-lived species (0.084) (Hamrick \& Godt, 1989); however, the values for these Lonicera spp. may be affected partially by the small sample sizes (increasing $G_{\mathrm{ST}}$ ), the comparatively small geographical area sampled (decreasing $G_{\mathrm{ST}}$ ) and differences in pollination systems and distance of seed dispersal. Naturalized outbreeding species that maintain large populations are likely to have little differentiation (Brown \& Marshall, 1981). The levels of genetic variation among the $L$. japonica populations we sampled are consistent with the prediction that these are large outbreeding populations.

Although species and population levels of genetic variability in $L$. japonica are high, they may still reflect genetic sampling, immigration and subsequent persistence of a subset of the variation present in its home range. Even with the likelihood of multiple introductions of L. japonica (Mack, 1991), the levels of variation found in the southeastern United States may be lower than variation in its native range because of founder effects. To our knowledge, there are no published studies on the allozyme variation in Asian populations of $L$. japonica.

An allopolyploid origin for L. sempervirens (Ammal \& Saunders, 1952) is supported to some degree by the allozyme patterns we observed, chromosome pairing patterns observed during meiosis in squashes of immature anthers (K. A. Schierenbeck, personal observation) and higher levels of variation (Brown \& Marshall, 1981). Although Hamrick et al., (1979) did not compare the levels of genetic variation observed in species with different ploidy levels, they did find that species with higher chromosome numbers had higher levels of genetic diversity. The distribution of $L$. sempervirens supports the hypothesis that a higher genetic variability in polyploids can result in a more widespread distribution than their native diploid congeners (Stebbins, 1971).

In another perennial species that has escaped from cultivation, Lathyrus latifolius, the mean genetic diversity is $0.207,81$ per cent of the loci are polymorphic and the mean number of alleles per polymorphic locus is 2.29 (Godt \& Hamrick, 1991). These values are high compared with those for other plant species (Hamrick \& Godt, 1989) and with values for other naturalized species with similar life history traits. Low levels of allozyme diversity are often found within weedy species but many of these are annual grasses and dicots that reproduce primarily by self-fertilization (Brown \& Marshall, 1981; Warwick, 1990). Hamrick et al. (1979) found that weedy and early successional species are less variable than species of mid-and late-successional stages. However, many of the weedy species in their review were selfing annuals and may not be directly comparable to long-lived outcrossing species such as these two Lonicera species.

Reviews of the allozyme literature have found that among 196 long-lived woody species for which genetic variation has been measured, only nine are for invasive angiosperms (Hamrick et al., 1979, 1992). All nine records report genetic variation in the species' home range. In these studies, all except one species (Acacia dealbata, for which data were collected from only one population) show higher levels of variation than expected for species with similar life history traits (Table 4). It should also be noted that all of these species except Eucalyptus obliqua are nitrogen fixers, a trait that is associated with the ability to invade new ranges rapidly (Vitousek, 1986). Rapid invasion through only a few introduction events may result in lower levels of genetic variability in the new range, but we lack historical confirmation of this scenario for $L$. japonica. Although most species with broad distributions have higher levels of genetic variability (Hamrick \& Godt, 1989), we found levels of polymorphism for 
Table 4 Summary of levels of variation within eight species of invasive woody angiosperms

\begin{tabular}{lccccccc}
\hline Species & $\begin{array}{c}\text { No. of } \\
\text { populations }\end{array}$ & $\begin{array}{c}\text { No. of } \\
\text { loci }\end{array}$ & $P_{\mathrm{s}}$ & $A_{\mathrm{s}}$ & $A_{\mathrm{es}}$ & $H_{\mathrm{es}}$ & Reference \\
\hline Robinia pseudoacacia & 23 & 40 & 97.5 & 2.92 & 1.52 & 0.344 & $\mathrm{a}$ \\
Eucalyptus obliqua & 4 & 3 & - & - & - & 0.489 & $\mathrm{~b}$ \\
Prosopis glandulosa & 1 & 13 & 61.5 & 1.92 & - & - & $\mathrm{c}$ \\
Prosopis pallida & 1 & 13 & 15.4 & 1.15 & - & - & $\mathrm{c}$ \\
Casuarina cunninghamiana & 6 & 21 & 77.7 & 2.00 & 1.17 & 0.145 & $\mathrm{~d}$ \\
Casuarina cunninghamiana & 20 & 19 & 100.0 & 2.79 & 1.40 & 0.287 & $\mathrm{e}$ \\
Acacia dealbata & 1 & 16 & - & - & - & 0.085 & $\mathrm{f}$ \\
Acacia melanoxylon & 1 & 19 & - & - & - & 0.300 & $\mathrm{f}$ \\
Acacia decurrens & 1 & 26 & - & - & - & 0.156 & $\mathrm{f}$ \\
\hline
\end{tabular}

Key to abbreviations: $P_{s}$, percentage polymorphic loci; $A_{\mathrm{s}}$, mean number of alleles per locus; $A_{\text {es }}$, effective number of alleles per locus; $H_{\mathrm{es}}$, genetic diversity.

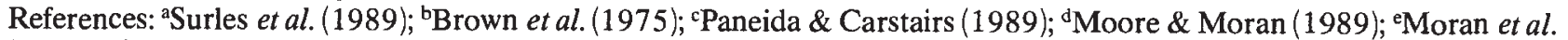

(1989a); 'Moran et al. (1989b).

these two Lonicera species that are higher than expected for invasive species in general. We are unaware of any other studies of the genetic diversity of introduced perennial woody species in their new ranges. Consequently, comparisons remain tenuous.

Life history characteristics that are associated with high genetic variability are also traits characteristic of many invasive woody perennials. High levels of genetic variability may allow species to invade diverse habitats, but quantitative growth characters might provide the adaptations necessary for the invasive species to outcompete native species (Sasek \& Strain, 1991; Schierenbeck, 1992). The identification of a particular combination of characteristics important to the success of an individual in any environment is best achieved through comparative studies of species with similar life history categories. Lonicera contains both aggressive alien and nonaggressive native woody species in North America. For example, L. maackii and L. tartarica are widespread alien weeds whereas $L$. dioica and $L$. flava are referred to as rare natives (Radford et al., 1968). Further investigation of native and nonindigenous species in this genus may elucidate differences that will help to explain their differential ability as invaders.

Patterns among the genetic characteristics of invasive species are gradually emerging, but certainly more information is needed. Consistent patterns among the genetic attributes of invaders may cease to be elusive if the examination of genetic variability is correlated with life history traits. Such correlations may eventually allow us to understand the relative importance of genetic variability in relation to other characteristics in the invasion process.

\section{Acknowledgements}

This research was supported under Contract No. DEAC09-76SROO-819 between the U.S. Department of Energy and the University of Georgia, NSF doctoral dissertation improvement grant BSR-8914717 to K.A.S. and R.N.M., Sigma Xi, the Hardman Foundation and The Nature Conservancy. The authors thank M. Rodgers and J. W. Eckert for help with collecting plant samples, D. E. and P. S. Soltis for the use of their laboratory during preliminary data collection, S. Sherman-Broyles, E. Berg, J. Tyrell, L. Manning and S. Dillard for laboratory assistance, M. D. Loveless and A. Schnabel for the use of the computer program for data analysis, and D. E. Soltis, A. Schnabel and S. Warwick for comments on the manuscript.

\section{References}

ADAMS, w. T. AND JOLY, R. J. 1980. Genetics of allozyme variants in loblolly pine. J. Hered., 71, 33-40.

AMMAL, E. K. J. AND SAUNDERS, B. 1952. Chromosome numbers in species of Lonicera. Kew Bull., 4, 539-541.

BAKER, H. G. 1965. Characteristics and modes of origin of weeds. In: Baker, H. G. and Stebbins, G. L. (eds) The Genetics of Colonizing Species, pp. 147-172. Academic Press, New York.

BAKER, H. G. 1974. The evolution of weeds. Ann. Rev. Ecol. Syst., 5, 1-24.

BAKER, H. G. 1986. Patterns of plant invasion in North America. In: Mooney, H. A. and Drake, J. A. (eds) Ecology of Biological Invasions of North America and Hawaii, pp. 44-57. Springer Verlag, New York. 
BARRETT, S. C. H. AND RICHARDSON, B. J. 1986. Genetic attributes of invading species. In: Groves, R. H. and Burdon, J. J. (eds) Ecology of Biological Invasions, pp. 21-33. Cambridge University Press, Melbourne, Australia.

BARRETT, S. C. H. AND SHORE, J. S. 1989. Isozyme variation in colonizing plants. In: Soltis, D. E. and Soltis, P. S. (eds) Isozymes in Plant Biology, pp. 106-126. Dioscorides Press, Portland, OR.

BROWN, A. H. D. AND MARSHALL, D. R. 1981. Evolutionary changes accompanying colonization in plants. In: Scudder, G. C. E. and Reveal, J. L. (eds) Colonization, Succession and Stability, pp. 351-363. Blackwell Scientific Publications, Oxford.

BROWN, A. H. D., MATHESON, A. C. AND ELDRIDGE, K. G. 1975. Estimation of the mating system of Eucalyptus obliqua L'Heret by using enzyme polymorphisms. Aust. J. Bot., 23, 931-949.

GODT, M. J. W. AND HAMRICK, J. L. 1991. Genetic variation in Lathyrus latifolius (Leguminosae). Am. J. Bot., 78 , 1163-1171.

GOTTLIEB, L. D. 1981. Gene numbers in species of Asteraceae that have different chromosome numbers. Proc. Natl. Acad. Sci. U.S.A., 78, 3726-3729.

GRAY, A. J. 1986. Do invading species have definable genetic characteristics? Phil. Trans. R. Soc. B, 314, 655-674.

HAMRICK, J. L. AND GODT, M. J. W. 1989. Allozyme diversity in plant species. In: Brown, A. H. D., Clegg, M. T., Kahler, A. L. and Weir, B. S. (eds) Plant Population Genetics, Breeding and Genetic Resources, pp. 43-63. Sinauer, Sunderland, MA.

HAMRICK, J. L., GODT, M. J. W. AND SHERMAN-BROYLES, S.L. 1992. Factors influencing levels of genetic diversity in woody plant species. New Forests, 6, 95-124.

HAMRICK, J. L., LINHART, Y. B. AND MITTON, J. B. 1979. Relationships between life history characteristics and electrophoretically detectable genetic variation in plants. Ann. Rev. Ecol. Syst., 10, 173-200.

HANDEL, S. N. 1983. Pollination ecology, plant population structure and gene flow. In: Real, L. A. (ed) Pollination Biology, pp. 163-211. Academic Press, New York.

HEDRICK, P. W. 1985. Genetics of Populations. Jones and Bartlett, Boston.

JoHnSGARD, P. A. 1983. The Hummingbirds of North America. Smithsonian Institution Press, Washington, DC.

LEATHERMAN, A. D. 1955. Ecological Life-history of Lonicera japonica Thunb. Ph.D. Thesis, University of Tennessee, Knoxville, TN.

LI, C. C. AND HORVTZ, D. G. 1953. Some methods of estimating the inbreeding coefficient. Am. J. Hum. Genet., 5, 107-117.

LOVELESS, M. D. AND HAMRICK, J. L. 1984. Ecological determinants of genetic structure in plant populations. Ann. Rev. Ecol. Syst., 15, 65-95.

MACK, R. N. 1985. Invading plants: their potential contribution to population biology. In: White, J. (ed.) Studies on Plant Demography: J. L. Harper Festschrift, pp. 127-142. Academic Press, London.

MACK, R. N. 1991. The commercial seed trade: an early disperser of weeds in the United States. Econ. Bot., 45, 257-273.
MITTON, J. B., LINHART, Y. B., HAMRICK, J. L. AND BECKMAN, J. S. 1977. Observations on the genetic structure and mating system of ponderosa pine in the Colorado front range. Theor. Appl. Genet., 51, 5-13.

MOORE, N. J. AND MORAN, G. F. 1989. Microgeographic patterns of allozyme variation in Casuarina cunninghamiana within and between the Murrumbidge and coastal drainage systems. Aust. J. Bot., 37, 181-192.

MORAN, G. F., BELL, J. C. AND TURNBULL, J. w. 1989a. A cline in genetic diversity in River she-oak (Casuarina cunninghamiana). Aust. J. Bot., 37, 169-180.

MORAN, G. F., MUONA, O. AND BELL, J. c. 1989 b. Breeding systems and genetic diversity in Acacia auriculiformis and $A$. crassicarpa. Biotropica, 21, 250-256.

NEI, M. 1973. Analysis of gene diversity in subdivided populations. Proc. Natl. Acad. Sci. U.S.A., 70, 3321-3323.

NEI, M. 1977. F-statistics and analysis of gene diversity in subdivided populations. Ann. Hum. Genet., 41, 225-233.

NEI, M. 1978. Estimation of average heterozygosity and genetic distance from a small number of individuals. Genetics, 89, 583-590.

oosting, H. J. 1942. An ecological analysis of the plant communities of the Piedmont, North Carolina. Am. Midl. Nat., 28, 1-126.

PANEIDA, F. D. AND CARSTAIRS, S. A. 1989. Isozymic discrimination of tropical Australian populations of mesquite (Prosopis spp.); implication for biological control. Weed Res., 29, 157-165.

RADFORD, A. E., AHLES, H. E. AND BELL, C, R. 1968. Manual of the Vascular Flora of the Carolinas. The University of North Carolina Press, Chapel Hill.

ROOSE, M. L. AND GOTTLIEB, L. D. 1976. Genetic and biochemical consequences of polyploidy in Tragopogon. Evolution, $\mathbf{3 0}$, $818-830$

SASEK, T. w. 1983. Growth and Biomass Allocation Patterns of Lonicera japonica Thunb. and Lonicera sempervirens $L$. under Carbon Dioxide Enrichment. M.S. Thesis, Duke University, Durham, NC.

SASEK, T. W. AND STRAIN, B. R. 1991. Effects of $\mathrm{CO}_{2}$ enrichment on the growth and morphology of a native and an introduced honeysuckle vine. Am. J. Bot., 78, 69-75.

SAX, K. AND KRIBS, D. A. 1930. Chromosomes and phylogeny in Caprifoliaceae. J. Arnold Arbort., 11, 147-153.

SCHIERENBECK, K. A. 1992. Comparative Ecological and Genetic Studies Between a Native (Lonicera sempervirens L.) and an introduced vine (L. japonica Thunb.). Ph.D. Thesis, Washington State University, Pullman, WA.

SHAW, C. R. AND PRASAD, R. 1970. Starch gel electrophoresis of enzymes - a comparison of recipes. Biochem. Genet., 4, 297-320.

SLEZAK, W. F. 1976. Lonicera japonica Thunb., an Aggressive Introduced Species in a Mature Forest Ecosystem. M.S. Thesis, Rutgers University, New Brunswick, NJ.

SNOW, B. AND SNOW, D. 1988. Birds and Berries, A Study of an Ecological Interaction. T. and A. D. Poyser, Calton, U.K.

SOLTIS, D. E., HAUFLER, C. H., DARROW, D. C., AND GASTONY, G. J. 1983. Starch gel electrophoresis of ferns: a compilation of grinding buffers, gel and electrode buffers, and staining schedules. Am. Fern J., 73, 9-27.

(c) The Genetical Society of Great Britain, Heredity, 75, 1-9. 
STEBBiNS, G. L. 1971. Chromosomal Evolution in Higher Plants. Edward Arnold, London.

SURLES, S. C., HAMRICK, J. L. AND BONGARTEN, B. C. 1989. Allozyme variation in black locust (Robinia pseudoacacia). Can. J. Forest Res., 19, 471-479.

VITOUSEK, P. 1986. Biological invasions and ecosystem properties: can species make a difference? In: Mooney, $\mathrm{H}$. A. and Drake, J. A. Drake (eds) Ecology of Biological Invasions of North America and Hawaii, pp. 163-176. Springer-Verlag, New York.

WADDINGTON, K. D. 1983. Foraging behavior of pollinators. In: Real, L. A. (ed.) Pollination Biology, pp. 213-239. Academic Press, New York.
WARWICK, S. I. 1990. Allozyme and life-history variation in five northwardly colonizing North American weed species. $P l$. Syst. Evol., 169, 41-54.

WEEDEN, N. F. AND WENDEL, J. F. 1989. Genetics of plant isozymes. In: Soltis, D. E. and Soltis, P. S. (eds) Isozymes in Plant Biology, pp. 46-72. Dioscorides Press, Portland, OR.

WORKMAN, P. L. AND NISWANDER, J. D. 1970. Population studies on southwestern Indian tribes. II. Local genetic differentiation in the Pagayo. Am. J. Hum. Genet., 22, 24-49.

WRIGHT, s. 1922. Coefficients of inbreeding and relationship. Am. Nat., 56, 330-338. 